\title{
The population growth and the nutritional status of Moina macrocopa feed with rice bran and cassava bran suspensions
}

\section{Perkembangan populasi dan status gizi Moina macrocopa yang diberi pakan suspensi dedak dan tepung ketela pohon}

\author{
Ahmad Shofy Mubarak², Dedi Jusadi'*, Muhammad Zairin Junior¹, Muhammad Agus \\ Suprayudi ${ }^{1}$
}

\author{
${ }^{1}$ Department of Aquaculture, Faculty of Fisheries and Marine Science, Bogor Agricultural University \\ Campus IPB Dramaga Bogor, West Java, Indonesia 16680 \\ ${ }^{2}$ Study Program of Aquaculture, Faculty of Fisheries and Marine, Universitas Airlangga \\ Campus C Mulyorejo Surabaya, East Java, Indonesia 60113 \\ *E-mail: siflounder@gmail.com,dedidj@ipb.ac.id
}

\begin{abstract}
Moina macrocopa culture density can be improved by optimizing the fecundity, and somatic growth through the regulation of quality and quantity of feed. The purpose of this study were to determined how to use effectively the rice bran and cassava bran Manihot utilisima suspension on Moina, based on population, neonates production, adult percentage, biomass, metabolisme and nutritional state. In this study, Moina were cultured for eighth days using four concentrations of rice bran suspension and three concentrations of cassava suspension. This research found that $M$. macrocopa culture with rice bran suspension has higher population, neonates production, adult percentage and biomass than its culture with cassava bran suspension $(\mathrm{P}<0.05)$. This study also found that Moina culture with rice bran suspension has higher total value of RNA, total value of DNA, the ratio RNA/ DNA, FCR, and concentration of protein and amino acid than Moina culture with cassava bran suspension. Treatment D with the initial rice bran suspension concentration was $0.3 \mathrm{~mL} / \mathrm{L}$ and was increased starting the second day and the end concentration on the eighth day was $1.2 \mathrm{~mL} / \mathrm{L}$ has highest peak population of Moina 17,975 ind/L in seventh day, weight wet biomass $439 \mathrm{mg} / \mathrm{L}$ in eighth day and lower FCR 0.94 .
\end{abstract}

Keywords: suspension, rice bran, cassava, population, ratio RNA/DNA

\begin{abstract}
ABSTRAK
Kepadatan populasi dalam budidaya Moina macrocopa dapat ditingkatkan dengan mengoptimalkan fekunditas dan pertumbuhan somatik melalui pengaturan kualitas dan kuantitas pakan. Penelitian ini bertujuan untuk menganalisis efektifitas pengunaan pakan suspensi dedak dan tepung ketela pohon Manihot utilisima dalam budidaya $M$. macrocopa terhadap populasi, produksi anak per induk, persentase dewasa, biomasa, FCR, dan metabolismenya (asam amino, DNA, RNA, dan RNA/DNA). Di dalam penelitian ini, M. macrocopa dibudidayakan selama delapan hari menggunakan empat konsentrasi suspensi dedak dan tiga konsentrasi suspensi tepung ketela pohon. Hasil penelitian ini menunjukkan bahwa, budidaya $M$. macrocopa dengan pakan suspensi dedak menghasilkan populasi, produksi anak/induk, persentase dewasa dan biomasa yang lebih tinggi dibandingkan budidaya Moina dengan pakan suspensi ketela pohon $(\mathrm{P}<0,05)$. Budidaya $M$. macrocopa dengan pakan suspensi dedak juga menghasilkan total RNA, total DNA dan nisbah RNA/DNA, konsentrasi protein, dan asam amino yang lebih tinggi dibandingkan Moina dengan pakan suspensi ketela pohon. Perlakuan D dengan pakan suspensi dedak awal 0,3 mL/L dan meningkat mulai hari kedua dengan konsentrasi hari kedelapan 1,2 mL/L menghasilkan puncak populasi tertinggi pada hari ketujuh sebanyak 17.975 ind/L, berat basah biomasa hari kedelapan kultur $439 \mathrm{mg} / \mathrm{L}$, dan FCR yang rendah yaitu 0,94 .
\end{abstract}

Kata kunci: suspensi, dedak, ketela pohon, populasi, nisbah RNA/DNA 


\section{INTRODUCTION}

Moina has become an important candidate as natural feed for both fish and shrimp larvae as a result of artemia cyts price increment (Dodson et al., 2010). It has a higher nutritional value compared to naupli and can breed and growth fast. It can tolerate low dissolved oxgyen (DO) level and a high amonnia concentration (Loh et al., 2013). Moina can be cultured using agricultural, animal, and food industry wastes as feed (Patil et al., 2010). However, the use of Moina macrocopa is limited due to its low commercial availibilty.

M. macrocopa culture with an initial innoculant of 40-50 individual/L using Chlorella spp. $\left(1.0 \times 10^{6} \mathrm{cell} / \mathrm{mL}\right)$ as feed resulted in producing about 15,000-20,000 individual/L, which was higher compared to Moina production using animal wastes (fowl and cow manures) i.e. 1,301 individual/L (45 individual/L) (Ventura et al., 2012; Siddque et al., 2004; Malla \& Banik, 2015). Moina culture using Chlorella spp, at a density of $1.0 \times 10^{6}$ cell $/ \mathrm{mL}$, generated a production of 12-14 larvae/broodstock (Malla \& Banik, 2015). According to Rietzler et al. (2014), $M$. macrocopa can reach a maximal fecundity of 37 eggs/broodstock and both fecundity and optimum population growth were obtained at water hardness of $50 \mathrm{mg} / \mathrm{L}$, a temperature of $25-31{ }^{\circ} \mathrm{C}, \mathrm{pH}$ of $7-8$ and DO higher than $4 \mathrm{mg} / \mathrm{L}$ (Tan \& Wang, 2010).

M. macrocopa population density could be enlarged by mean of increasing fecundity and decreasing the reproductive period by manipulating both quality and quantity of the feed (Hakima et al., 2013), including protein concentration, amino acids concentration (Koch et al., 2011), lipid concentration (Wacker \& Creuzburg, 2007), and vitamin B (Mehdipour et al., 2011). M. macrocopa fecundity and growth decreased when the population density increased and both feed quality and quantity decreased (Loh et al., 2016; Zadereev \& Lopotina, 2012).

Rice bran is a potential feed for Moina since it contains various nutrients such as protein (12-13\%), lipid (16-20\%), linoleic acid $(6.35-6.85 \%)$, acids $\alpha$ linolenate $(0.2-0.27 \%)$, vitamin $B$, and minerals (6-9\%), which are dominated by calcium and iron (Faria et al., 2012; Murtaza et al., 2011). Another agricultural product candidate that is abundantly available is cassava bran (Manihot utilisima) that also contains nutrients such as carbohydrates (56-94\%), Vitamin B1 (thiamin) (2.16-48 $\mathrm{\mu g} / \mathrm{g})$, high vitamin $\mathrm{C}(50-510 \mathrm{\mu g} / \mathrm{g})$, low protein content (1.5-4.7\%,), lipid (0.3-3.2\%), and lower mineral compared to rice bran (Salvador et al., 2014; Faria et al., 2012).

Rice bran was used as feed in both Daphnia and Artemia cultures (Sorgeloos et al., 1980; Depauw et al., 1981). Rice bran and cassava bran could directly be used as $M$. macrocopa feed, although they have to be proccessed into small particles suspension in order to fit the the mouth of M. macrocopa. Protein and amino acids concentrations of the feed directly affect fecundity and population growth of $M$. macrocopa. Indeed, the amino acids, arginine, affects both endocrine system and reproduction (Jobgen et al., 2006), while histidine affects DNA and protein synthesis. Glycine, tirocsin, phenilalanine, and lysine affect the speed of embryo development in the incubating cavity (Li et al., 2008).

Moina fecundity and population growth are also affected by fat and fatty acids concentrations. Cholesterol is a proccursssor for hormone formation that could not be synthesized by microcrusteacean (Nagaraju, 2011). In Cladocera, it plays a role in increasing somatic growth, while PUFAs (polyunsaturated fatty acids) play important roles in reproduction, growth performance, and survival (Fereidouni et al., 2013). High PUFAs concentration hampers somatic growth and induces sexual reproduction in Daphnia magna that results in ephippia (Choi et al., 2016).

Base on the above information, it is believed that both rice bran and cassava bran suspensions with specific concentrations can enhance both M. macrocopa fecundity and population growth. The present research was aimed at determining the effectiveness of using rice bran and cassava bran suspensions in $M$. macrocopa culture on population growth, metabolism, nutritional status, protein and amino acids contents.

\section{MATERIALS AND METHODS}

\section{Research design}

A completely randomised design with two major parameters i.e. rice bran suspension concentration and cassava bran suspension concentration, were used in the present research. Rice bran suspension consisted of 4 treatments (A, B, C, and D), while the cassava bran suspension had 3 treatments (E, F, and G). Each treatment was replicated 4 times. Both rice bran and cassava bran specific concentrations were 
determined in a preliminary research, where the concentration of $0.3 \mathrm{~mL} / \mathrm{L}$ was discerned as the optimum concentration that sustains both survival and reproduction of $M$. macrocopa (at a maximal level) at the beginning of the rearing period. Rice bran and cassava bran concentrations of $1.2 \mathrm{~mL} / \mathrm{L}$ was the concentration that generated a hardness level that did not affect $M$. macrocopa survival level. M. macrocopa population was observed to decrease with a cassava bran concentration of 0.6 $\mathrm{mL} / \mathrm{L}$, thus, was not used in the present study.

Both rice bran and cassava bran suspension concentrations were $0.3 \mathrm{~mL} / \mathrm{L}$ on the first day of the research and increased on the second day (according to each treatment) up to final concentrations on day 8 of the research. The treatment were as follows: final rice bran suspension concentration of $0.6 \mathrm{~mL} / \mathrm{L}$ (A), final rice bran suspension concentration of $0.8 \mathrm{~mL} / \mathrm{L}$ (B), final rice bran suspension concentration of $1.0 \mathrm{~mL} / \mathrm{L}(\mathrm{C})$, final rice bran suspension concentration of $1.2 \mathrm{~mL} / \mathrm{L}$ (D), final cassava bran suspension concentration of $0.8 \mathrm{~mL} / \mathrm{L}(\mathrm{E})$, final cassava bran suspension concentration of $1.0 \mathrm{~mL} / \mathrm{L}(\mathrm{F})$, and final cassava bran suspension concentration of $1.2 \mathrm{~mL} / \mathrm{L}(\mathrm{G})$.

\section{Preparation of rice bran and cassava bran suspensions}

Hundred grams of both rice bran and cassava bran were separately suspended in $500 \mathrm{~mL}$ water (from a water tank) using a blender at a speed of $2000 \mathrm{rpm}$ for 5 minutes (twice) in order to increase the concentration and decrease organic matter size in the suspension. A second suspension process was performed 30 minutes after the first, then filtered using a net $(2 \mathrm{~mm}, 0.1 \mathrm{~mm})$ and nilon $(40 \mu \mathrm{m})$. Finally, water was added to the obtained suspension (up to $500 \mathrm{~mL}$ ).

Proximate analysis results of cassava bran suspension revealed that it contained organic matters $(72 \mathrm{mg} / \mathrm{mL})$, protein $(0.4 \%)$, and fat $(0.02 \%)$, while rice bran suspension contained organic matters $(74 \mathrm{mg} / \mathrm{mL})$, protein $(0.83 \%)$, and fat $(0.79 \%)$.

\section{Culture medium}

Water from a water tank in the faculty of fisheries and marine science (Bogor Agricultural University) was used as medium for M. macrocopa culture in the present study. Water from the tank was accommodated in a $1000 \mathrm{~L}$ fiber tank and used as water supply during $M$. macrocopa culture. Water was aerated for 3 days and filtered using a $40 \mu \mathrm{m}$ nylon filter prior to stocking it in experimental tanks in order to dipose of other zooplankton competitors.

\section{Innoculant availability and $M$. macrocopa culture}

M. macrocopa used in the present study was brought from Surabaya and individually cultured ( 1 individual/20 $\mathrm{mL}$ ) during several generations to obtain a high $M$. macrocopa seed quality (in terms of growth and reproduction). Afterwards, M. macrocopa was cultured at a density of 20 individual/L with water volumes ranging between $300 \mathrm{~mL}$ and $10 \mathrm{~L}$, and acclimatised to both feed (rice bran and cassava bran) for two months. Finally, seeds from the $10 \mathrm{~L}$ water treatment was used as innoculant in the present study.

Twenty individuals per liter water was used as innoculant in the present study and cultured in 10 L containers. M. macrocopa culture lasted for 8 days in an indoor room (closed) with photoperiods of 900-1250 lux in the afternoon and 50-100 lux at night. During the first two days, all of the treatments received the same amount of feed i.e. $0.3 \mathrm{~mL} / \mathrm{L}$. On the second day, various feeding rate were applied according to each treatment as presented in Table 1, and feeding (50\% from the daily concentration) was done twice daily at 8.00-9.00 am and 7.00-8.00 pm. During the rearing period, both water and container exchange were performed every two days, starting on day 3 until day 7 . Thirty three percent (33\%) of the water in previous container was disposed and $M$. macrocopa placed into a new container and filled with the percentage of disposed water (until it reached $10 \mathrm{~L}$ ). container exchange was performed in order to prevent the formation of filamentous layer that could trap M. macrocopa, leading to death.

\section{Tested parameters \\ Population growth}

Sampling was carried out by randomly collecting $100 \mathrm{~mL}$ of water from 5 collecting points (both center and corners) after turning off the aeration system for 15 minutes. Data on population, total broodstock, and offspring were collected from day 2 until day 8 of the culturing period. In addition to the sampling, $M$. macrocopa broodstock, ready for spawning, were selected (20-40 individual) and stocked at a density of 66 individual/L. offspring production per broodstock and $M$. macrocopa broodstock percentage were determined using the following formula: 
Table 1. M. macrocopa volume air $10 \mathrm{~L}$ Total rice bran and cassava bran daily suspension concentrations in $M$. Macrocopa culture in $10 \mathrm{~L}$ water

\begin{tabular}{cccccccc}
\hline \multirow{2}{*}{ Culture days } & $\mathrm{A}$ & $\mathrm{B}$ & $\mathrm{C}$ & $\mathrm{D}$ & $\mathrm{E}$ & $\mathrm{F}$ & $\mathrm{G}$ \\
\cline { 2 - 8 } & & & & $\mathrm{mL} / 10 \mathrm{~L}$ & & & \\
\hline 0 & 3 & 3 & 3 & 3 & 3 & 3 & 3 \\
1 & 3 & 3 & 3 & 3 & 3 & 3 & 3 \\
2 & 3.2 & 3.3 & 3.4 & 3.5 & 3.3 & 3.4 & 3.5 \\
3 & 3.6 & 3.8 & 4.1 & 4.3 & 3.8 & 4.1 & 4.3 \\
4 & 4 & 4.6 & 5 & 5.4 & 4.6 & 5 & 5.4 \\
5 & 4.5 & 5.3 & 6 & 6.8 & 5.3 & 6 & 6.8 \\
6 & 4.9 & 6 & 7.2 & 8.4 & 6 & 7.2 & 8.4 \\
7 & 5.4 & 7 & 8.6 & 10.2 & 7 & 8.6 & 10.2 \\
8 & 6 & 8 & 10 & 12 & 8 & 10 & 12 \\
\hline Total (mL) & 37.6 & 44.0 & 50.3 & 56.6 & 44.0 & 50.3 & 56.6 \\
\hline N & & &
\end{tabular}

Note: A, B, C and D are rice bran suspension; E, F, and $\mathrm{G}$ are cassava bran suspension.

Offspring production (individual $/$ broodstock $)=$ Number of $M$. macrocopa offspring

Number of $M$. macrocopa broodstock

Broodstock percentage $(\%)=$

Number of M. macrocopa offspring $\times 100$

Number of M. macrocopa broodstock

Harvesting and $M$. macrocopa final weight measurement (wet weight) were carried out on day 8 of the research. M. macrocopa was dried using a paper tissue on a nylon filter before weighing and the mentioned data was used to determine FCR as follows:

$$
\mathrm{FCR}=\mathrm{F} /(\mathrm{Wt}-\mathrm{Wo})
$$

FCR was determined based on the total feed weight (F), initial weight (Wo), and final weight (Wt) of M. macrocopa.

Water quality parameters such as dissolved oxygen, $\mathrm{pH}$, temperature, total ammonia, and hardness were also measured throughout the research.

\section{M. macrocopa DNA and RNA analysis}

RNA and DNA concentrations were determined based on Ramalho et al. (2004) method. RNA and DNA were isolated from $20 \mathrm{mg}$ M. macrocopa (wet weight), that were collected on day 5 and day 7 of the culture ( $7 \mathrm{~h}$ after morning feeding). DNA and RNA concentrations were measured using Gene Quant from Biotech Pharmacy with absorbance $(\lambda=260 \mathrm{~nm}$ and $280 \mathrm{~nm})$. DNA and
RNA concentration results was used to determine RNA/DNA ratio as indicator for nutritional status of $M$. macrocopa from culture systems using rice bran and cassava bran suspensions.

Protein, feed amino acids and M. macrocopa analysis

Rice bran, cassava bran, and M. macrocopa were collected from each group of treatment on day 8 and used to analyse amino acids content by mean of a high-performance liquid chromatography (HPLC) (Hewlett Packard Series 1.100) and proximate test based on AOAC (1995) method.

\section{Data analysis}

Data on population, fecundity, broodstock percentage, biomass, DNA, RNA, RNA/DNA ratio, and FCR were analysed using ANNOVA, which was followed by a Duncan's post-hoc comparison test if significant differences were found. Data on amino acids concentration and water quality were descriptively analysed.

\section{RESULTS AND DISCUSSION}

\section{Results}

M. macrocopa culture using rice bran suspension resulted in higher population peaks compared to cassava bran suspension. Treatment $D$ had the highest population among rice bran and cassava bran treatments, starting on day 3 until the population peak $(17,975$ individual/L) on day 7. M. macrocopa culture using cassava bran with the same concentration (treatment $\mathrm{G}$ ) resulted in 
a population peak of 1,970 individual/L (Figure 1.).

The differences in $M$. macrocopa population were consequences of differences in broodstock fecundity and $M$. macrocopa fed on rice bran suspension produced about 13.25 individual per broodstock on the $2^{\text {nd }}$ day, which decreased to $10.50-12.75$ individual on the $3^{\text {rd }}$ day. The mentioned performances were higher than those of M. macrocopa fed on cassava bran suspension i.e. about $3.39-3.92$ individual on the $2^{\text {nd }}$ day and $3.42-3.5$ individual on the $3^{\text {rd }}$ day. Increasing the population density resulted in a decrease in offspring production per broodstock, which was about 2.0-2.25 individual in rice bran suspension treatment, but higher compared to cassava bran suspension, being about $0.25-0.75$ individual (Figure 2).

Fecundity of M. macrocopa broodstock with low cassava bran suspension resulted in a higher percentage of broodstock compared to that of rice bran suspension. M. macrocopa cultured with cassava bean suspension had higher $M$. macrocopa broodstock on the $3^{\text {rd }}$ day $(30-32 \%$ of the total population) than in the rice bran suspension (3.2-3.3\% of the total population). $M$. macrocopa broodstock population increased after the $3^{\text {rd }}$ day with the highest percentage on day 7 i.e. $50 \%$ of the total population resulting from $M$. macrocopa culture using cassava bran suspension (treatment E). The highest $M$. macrocopa broodstock percentage in the culturing system using rice bran suspension was $42.5 \%$ of the total population (treatment D) on the day 8 (Figure 3).

The final biomass of M. macrocopa cultured in rice bran suspension (280-439 $\mathrm{mg} / \mathrm{L}$ ) was higher compared to that of cassava bran suspension (31-57 mg/L) (Table 2). M. macrocopa cultured with rice bran suspension as feed (treatment D) had the highest biomass i.e. $439 \mathrm{mg} / \mathrm{L}$ with a FCR of 0.94, while M. macrocopa cultured using cassava powder suspension (treatment E) had the lowest biomass, being $31 \mathrm{mg} / \mathrm{L}$, with a FCR of 14.13 (Table 2).

Protein and amino acids concentrations of $M$. macrocopa cultured with rice bran suspension were higher compared to those of $M$. macrocopa cultured with cassava bran suspension. $M$. macrocopa cultured with rice bran suspension had a protein content of $3.78 \%$ (wet weight), while $M$. macrocopa cultured with cassava bran suspension had a protein content of $2.57 \%$ (wet weight) (Table 3 ). Both protein and amino acids concentrations in rice bran suspension were higher compared to cassava bran suspension. For instance, rice bran suspension had an arginine concentration of $3.82 \%$, while arginine was only $0.89 \%$ of the total protein in cassava bran suspension. M. macrocopa cultured in cassava bran suspension had higher glutamate (11.47\%) and phenylalanine (3.98\%)

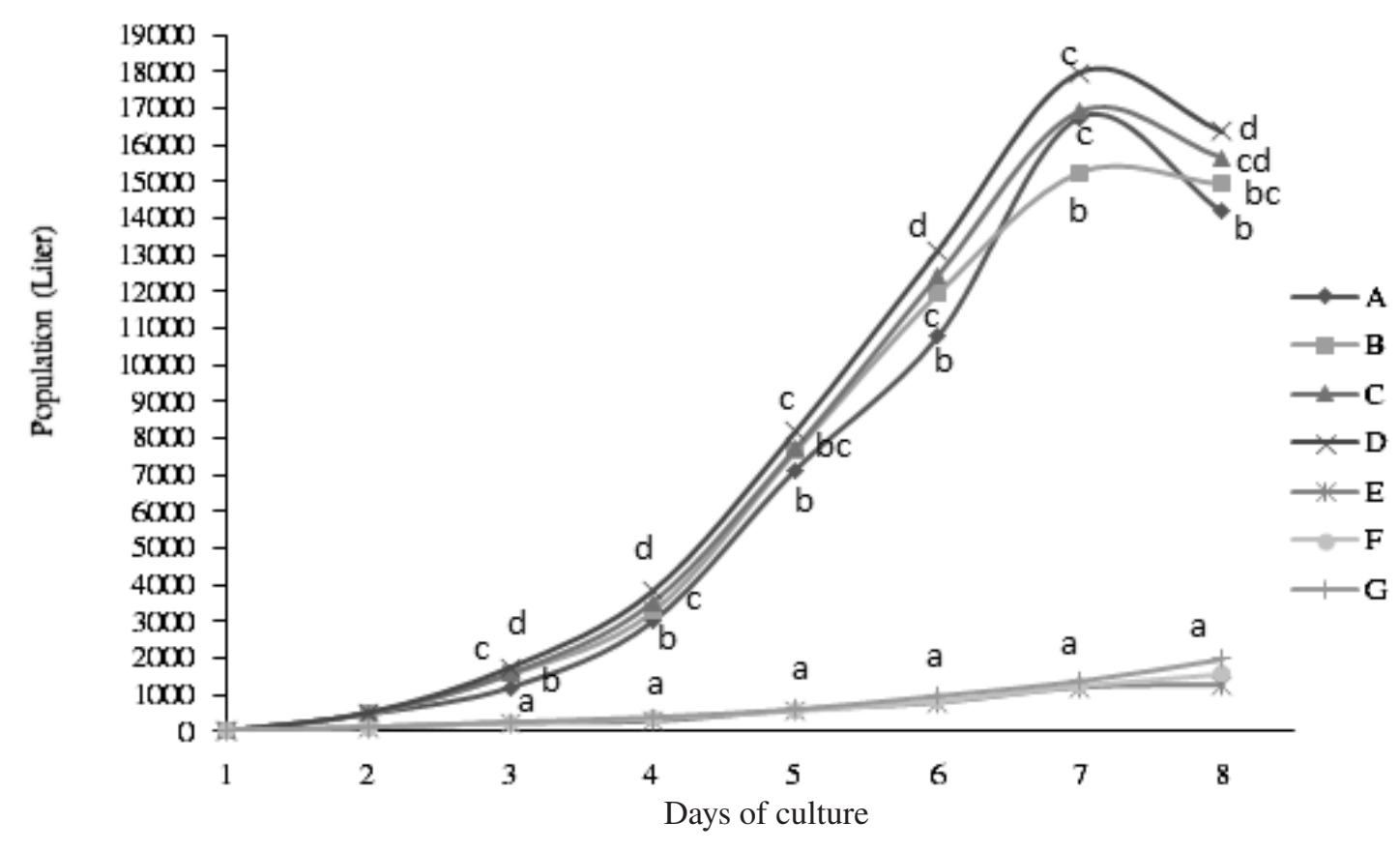

Figure 1. Population of M. macrocopa using rice bran suspension (A, B, C, D) and cassava tree suspension (E, F, $\mathrm{G})$. Different letters on the same day indicate significant differences $(\mathrm{P}<0.05)$. 
concentrations. However, the concentrations of the other amino acids were lower in cassava bran suspension compared to M. macrocopa cultured in rice bran suspension (Table 3).

M. macrocopa fed on rice bran suspension had a total DNA of $0.272-0.292 \mu \mathrm{g} / \mu \mathrm{g}$ on day 5 and the highest total DNA, $0.292 \mu \mathrm{g} / \mu \mathrm{g}$, was observed in treatment A. Total DNA experienced a decrease on day 7 with $0.119 \mu \mathrm{g} / \mu \mathrm{g}$ as the highest $M$. macrocopa DNA value (treatment E) (Table 4). M. macrocopa fed on rice bran suspension had a RNA of $0.055-0.069 \mu \mathrm{g} / \mu \mathrm{g}$ on day 5 with the highest total RNA of $0.069 \mu \mathrm{g} / \mu \mathrm{g}$ in treatment B. Total RNA experienced a decrease on day 7 except in treatment B with a total RNA of 0.083 $\mu \mathrm{g} / \mu \mathrm{g}$.

The RNA/DNA ratio of $M$. macrocopa on day 5 ranged between $0.20-0.24$ and experienced an increase on day 7 i.e. $0.36-0.82$ in M. macrocopa fed on rice bran suspension and $0.32-0.45$ in $M$. macrocopa fed on cassava bran suspension. The highest $M$. macrocopa RNA/DNA ratio (on day 7) was observed in treatment $B$, being 0.82 and the lowest in treatment E, being 0.32 (Table 4).

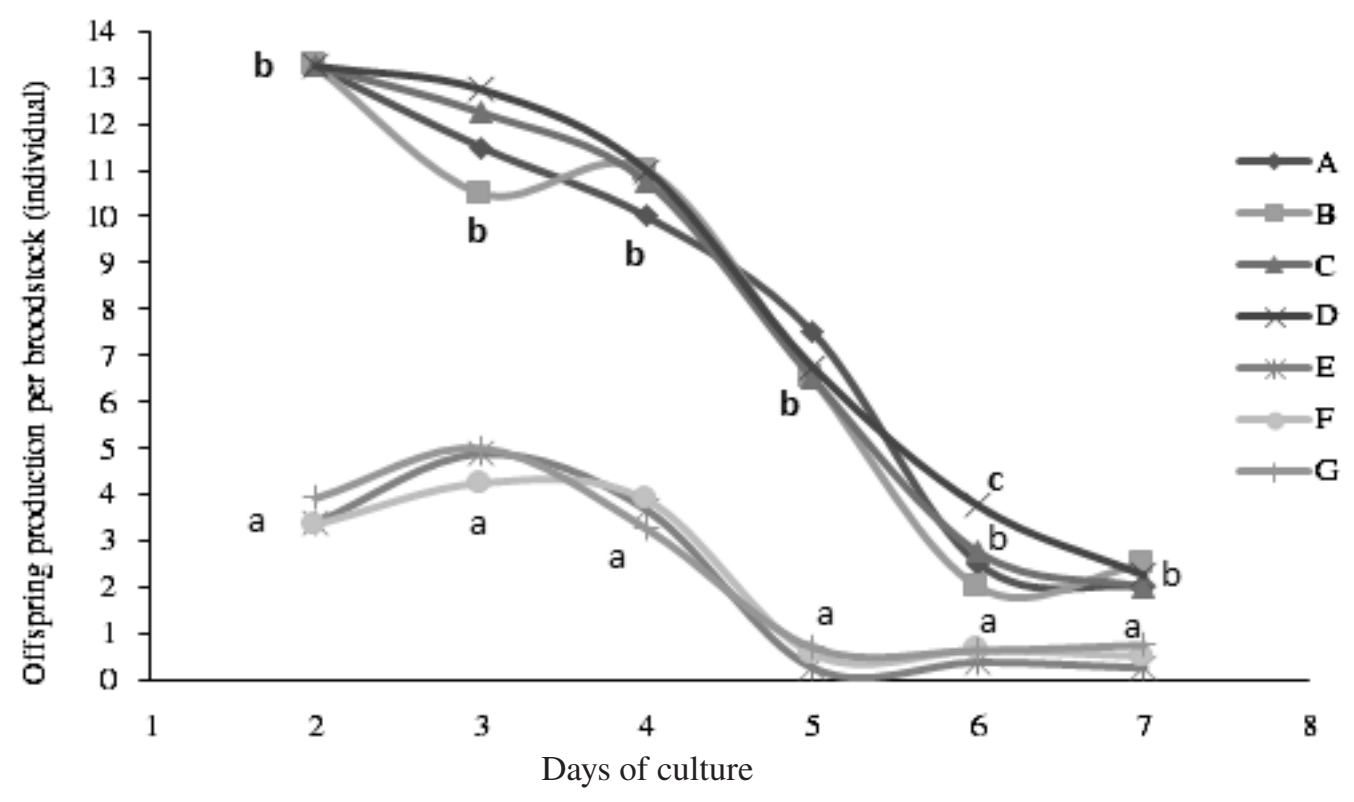

Figure 2. M. macrocopa offspring production per broodstock in rice bran suspension $(\mathrm{A}, \mathrm{B}, \mathrm{C}, \mathrm{D})$ and cassava tree suspension $(\mathrm{E}, \mathrm{F}, \mathrm{G})$. Different letters on the same day indicate significant differences $(\mathrm{P}<0.05)$.

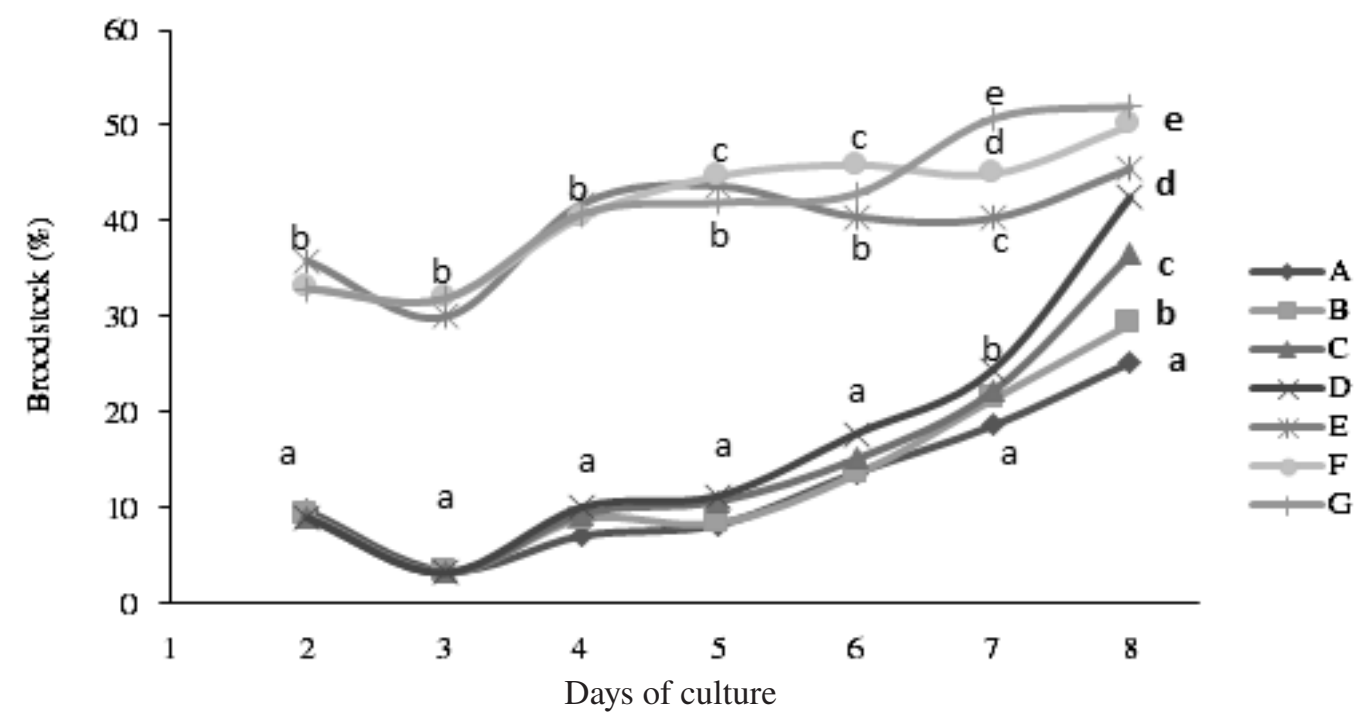

Figure 3. M. macrocopa broodstock percentage during the culturing period using rice bran suspension (A, B, C, D) and cassava powder suspension $(\mathrm{E}, \mathrm{F}, \mathrm{G})$. Different letters on the same day indicate significant differences $(\mathrm{P}<0.05)$ 
Table 2. M. macrocopa biomass and FCR fed on rice bran and cassava bran suspensions

\begin{tabular}{|c|c|c|c|c|c|c|c|}
\hline \multirow{3}{*}{ Parameters } & \multicolumn{7}{|c|}{ Treatments } \\
\hline & \multicolumn{4}{|c|}{ Rice bran suspension } & \multicolumn{3}{|c|}{ Cassava bran suspension } \\
\hline & A & $\mathrm{B}$ & $\mathrm{C}$ & $\mathrm{D}$ & $\mathrm{E}$ & $\mathrm{F}$ & G \\
\hline $\begin{array}{l}\text { Population } \\
\text { on day } 8 \\
\left(\times 10^{3} \mathrm{ind} / \mathrm{L}\right)\end{array}$ & $14.2 \pm 0.36 b$ & $14.9 \pm 0.71 \mathrm{bc}$ & $15.6 \pm 1.01 \mathrm{~cd}$ & $16.3 \pm 1.35 d$ & $1.27 \pm 0.46 \mathrm{a}$ & $1.56 \pm 0.18 \mathrm{a}$ & $1.97 \pm 0.19 \mathrm{a}$ \\
\hline $\begin{array}{l}\text { Feed weight } \\
\text { (g) }\end{array}$ & 7.52 & 8.82 & 10.06 & 11.32 & 8.8 & 10.06 & 11.32 \\
\hline $\begin{array}{l}\text { Feed } \\
\text { weight in } \\
\text { suspensions } \\
\text { (g) }\end{array}$ & 2.71 & 3.16 & 3.62 & 4.08 & 3.27 & 3.74 & 4.21 \\
\hline $\begin{array}{l}\text { Moina } \\
\text { initial } \\
\text { weight } \\
(\mathrm{mg} / \mathrm{L})\end{array}$ & 2.8 & 2.8 & 2.8 & 2.8 & 2.8 & 2.8 & 2.8 \\
\hline $\begin{array}{l}\text { Moina final } \\
\text { weight } \\
(\mathrm{mg} / \mathrm{L})\end{array}$ & $280 \pm 14 b$ & $322 \pm 30 \mathrm{c}$ & $364 \pm 44 d$ & $439 \pm 40 \mathrm{e}$ & $31 \pm 14 a$ & $41 \pm 90 \mathrm{a}$ & $57 \pm 60 a$ \\
\hline FCR & $0.98 \pm 0.1 \mathrm{a}$ & $1.00 \pm 0.1 \mathrm{a}$ & $1.01 \pm 0.1 \mathrm{a}$ & $0.94 \pm 0.1 \mathrm{a}$ & $14.13 \pm 7.4 b$ & $10.30 \pm 2.0 b$ & $7.82 \pm 1.0 \mathrm{~b}$ \\
\hline
\end{tabular}

Note: A, B, C, and D are rice bran suspension; E, F, and G are cassava bran suspension. Different letter in the same row showed the significant different between the treatment $(\mathrm{P}<0.05)$.

Water quality parameters were observed to support M. macrocopa growth (Table 5). M. macrocopa cultured with rice bran suspension had a dissolved oxygen of $3.9 \mathrm{mg} / \mathrm{L}$, while that of the cassava bran suspension was $4.0-5.0 \mathrm{mg} / \mathrm{L}$. In addition, total ammonia and $\mathrm{pH}$ were $0.51 \mathrm{mg} / \mathrm{L}$ and 7.3-7.5, respectively.

\section{Discussion}

M. macrocopa population density could be enlarged by mean of increasing fecundity and decreasing the reproductive period by manipulating both quality and quantity of the feed (Hakima et al., 2013), including protein concentration, amino acids concentration (Koch et al., 2011), lipid concentration (Wacker \& Creuzburg, 2007), and vitamin B (Mehdipour et al., 2011). Feed quantity and quality directly affect population growth and survival rate (Zadereev \& Lopotina, 2012; Hakima et al., 2013). M. macrocopa population peak in rice bran suspension occurred on day 7 , about 13.25 individual, which was higher than that of cassava bran on day 8 (1,975 individual/L). This was due to a high reproductive capacity of rice bran suspension (13.25 individual) compared to cassava bran suspension (4.00 individual). Observation results also showed that M. macrocopa culture using rice bran suspension can accelerate the reproductive cycle, leading to first reproduction within $55 \mathrm{~h}$ and consecutively every $18-21 \mathrm{~h}$.

Cladocera fecundity is affected by factors such protein concentration, fat, and amino acids (especially arginine and histidine) (Koch et al., 2011). Feed protein will be digested into amino acids using various networks to synthesize new protein during growth and reproduction, or even change the existing protein ( $\mathrm{Li}$ et al., 2008). Increments in arginine and histidine concentrations in feed can increase not only fecundity but also offspring development (Koch et al., 2011). Indeed, arginine affects endocrine regulation, and reproduction (Jobgen et al., 2006; Chen et al., 2013), while histidine affects both DNA and protein synthesis ( $\mathrm{Li}$ et al., 2008). Rice bran suspension used in the present study contained protein $(0.83 \%)$ and fat $(0.79 \%)$ that were higher compared to those of cassava bran suspension $(0.4 \%$ and $0.02 \%$, respectively). In addition, arginine $(3.82 \%)$ and histidine $(1.61 \%)$ concentrations were also higher in rice bran suspension compared to cassava bran $(0.89 \%$ and $0.56 \%$, respectively).

M. macrocopa fed on rice bran suspension resulted in offspring production per broodstock (on the second day) higher (13.25 individual) than that fed on cassava bran suspension $(4.00$ individual), which was a consequence of high 
Table 3. M. macrocopa amino acids concentrations (\% amino acid weight per protein weight) fed on rice bran and cassava bran suspensions.

\begin{tabular}{|c|c|c|c|c|}
\hline Parameters & $\begin{array}{l}\text { M. macrocopa fed } \\
\text { on rice bran }\end{array}$ & $\begin{array}{l}\text { M. macrocopa fed } \\
\text { on cassava bran }\end{array}$ & $\begin{array}{c}\text { Rice bran } \\
\text { suspension }\end{array}$ & $\begin{array}{c}\text { Cassava bran } \\
\text { suspension }\end{array}$ \\
\hline Protein $\%\left({ }^{w} /{ }_{w}\right)$ & 3.78 & 2.57 & 1.38 & 0.51 \\
\hline Amino acid $\%\left({ }^{w} /{ }_{w}\right)$ & 2.98 & 1.86 & 0.70 & 0.10 \\
\hline \multicolumn{5}{|c|}{ Essential amino acids (\%) } \\
\hline Leucine & 6.80 & 6.48 & 4.29 & 1.81 \\
\hline Arginine & 5.72 & 4.85 & 3.82 & 0.89 \\
\hline Lysine & 6.39 & 3.33 & 2.11 & 0.59 \\
\hline Histidine & 2.32 & 2.13 & 1.61 & 0.56 \\
\hline Valine & 5.13 & 5.06 & 3.03 & 1.22 \\
\hline Phenylalanine & 3.36 & 3.98 & 2.89 & 1.03 \\
\hline Threonine & 4.11 & 3.97 & 2.33 & 1.02 \\
\hline Methionine & 1.95 & 1.88 & 1.27 & 0.35 \\
\hline Isoleucine & 4.21 & 4.10 & 2.13 & 1.20 \\
\hline \multicolumn{5}{|c|}{ Non-essential amino acids $(\%)$} \\
\hline Glutamine & 11.37 & 11.47 & 8.61 & 3.60 \\
\hline Asparagine & 8.06 & 7.73 & 4.80 & 2.39 \\
\hline Glycine & 4.58 & 4.08 & 3.17 & 1.21 \\
\hline Serine & 4.26 & 4.09 & 2.69 & 1.47 \\
\hline Alanine & 5.95 & 5.72 & 4.31 & 1.67 \\
\hline Tyrosine & 4.58 & 3.31 & 3.42 & 1.51 \\
\hline
\end{tabular}

Table 4. Total DNA, RNA, and RNA/DNA ratio concentrations of $M$. macrocopa fed on rice bran and cassava bran suspension.

\begin{tabular}{|c|c|c|c|c|c|c|c|}
\hline \multirow{2}{*}{\multicolumn{2}{|c|}{ Treatments }} & \multicolumn{3}{|c|}{ Day 5} & \multicolumn{3}{|c|}{ Day 7} \\
\hline & & $(\mathrm{RNA}) \mu \mathrm{g} / \mu \mathrm{g}$ & (DNA) $\mu \mathrm{g} / \mu \mathrm{g}$ & RNA/DNA & $(\mathrm{RNA}) \mu \mathrm{g} / \mu \mathrm{g}$ & (DNA) $\mu \mathrm{g} / \mu \mathrm{g}$ & RNA/DNA \\
\hline \multirow{4}{*}{ 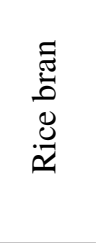 } & A & $0.066 \pm 0.001 \mathrm{a}$ & $0.292 \pm 0.008 \mathrm{a}$ & $0.23 \pm 0.01 \mathrm{a}$ & $0.034 \pm 0.000 \mathrm{a}$ & $0.078 \pm 0.001 b$ & $0.43 \pm 0.01 b$ \\
\hline & B & $0.069 \pm 0.001 \mathrm{a}$ & $0.284 \pm 0.010 \mathrm{a}$ & & & $0.100 \pm 0.001 \mathrm{ab}$ & $0.82 \pm 0.02 \mathrm{a}$ \\
\hline & $\mathrm{C}$ & $0.055 \pm 0.001 b$ & $0.272 \pm 0.006 \mathrm{ab}$ & $0.20 \pm 0.01 \mathrm{ab}$ & $0.023 \pm 0.000 \mathrm{c}$ & $0.065 \pm 0.007 \mathrm{~b}$ & $0.36 \pm 0.03 b$ \\
\hline & $\mathrm{D}$ & $0.056 \pm 0.005 b$ & $0.246 \pm 0.002 b$ & $0.23 \pm 0.02 \mathrm{a}$ & $0.031 \pm 0.001 b c$ & $0.067 \pm 0.001 b$ & $0.46 \pm 0.02 \mathrm{ab}$ \\
\hline \multirow{3}{*}{ 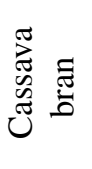 } & $\mathrm{E}$ & $0.043 \pm 0.002 \mathrm{c}$ & $0.213 \pm 0.018 b c$ & $0.20 \pm 0.03 \mathrm{ab}$ & $0.039 \pm 0.00 \mathrm{ab}$ & $0.119 \pm 0.006 a$ & $0.32 \pm 0.02 \mathrm{c}$ \\
\hline & $\mathrm{F}$ & $0.043 \pm 0.001 \mathrm{c}$ & $0.179 \pm 0.014 \mathrm{c}$ & $0.24 \pm 0.02 \mathrm{a}$ & $0.037 \pm 0.001 b$ & $0.096 \pm 0.000 \mathrm{~b}$ & $0.38 \pm 0.01 b$ \\
\hline & $\mathrm{G}$ & $0.048 \pm 0.001 b$ & $0.255 \pm 0.005 b$ & $0.19 \pm 0.01 b$ & $0.016 \pm 0.001 \mathrm{c}$ & $0.035 \pm 0.001 \mathrm{c}$ & $0.45 \pm 0.03 b$ \\
\hline
\end{tabular}

Note: A, B, C, and D are rice bran suspension; E, F, and $\mathrm{G}$ are cassava bran suspension. Different letter in the same column showed the significant different between the treatment $(\mathrm{P}<0.05)$.

protein and amino acids (arginine and histidine) concentrations in rice bran $(61.82 \%$ higher than cassava bran suspension). Lysine concentration in $M$. macrocopa fed on cassava bran suspension (3.33 g/100 g protein) was lower compared to that of M. macrocopa fed on rice bran suspension (6.39 $\mathrm{g} / 100 \mathrm{~g}$ protein), indicating a lysine deficiency that caused a decrease in embryo growth in the embryonic developmental cavity (Li et al., 2008).

Fat concentration in Cladosera D. magna feed affects the allocated energy from metabolism. Indeed, cholesterol is a precursor in hormone formation that cannot be synthesized in microcrustacean (Nagaraju, 2011) and plays a role 
Table 5. Water quality parameters of $10 \mathrm{~L}$ M. macrocopa using rice bran and cassava bran suspensions

\begin{tabular}{lccc}
\hline \multicolumn{1}{c}{ Water quality } & Research results & Optimal conditions & References \\
\hline Dissolved oxygen $(\mathrm{mg} / \mathrm{L})$ & $5.30-3.92$ & $>3.50$ & Miah et al. $(2013)$ \\
$\mathrm{pH}$ & $7.8-7.4$ & $7.0-8.0$ & Miah et al. $(2013)$ \\
Ammonia $\left(\mathrm{mg} / \mathrm{L} \mathrm{NH} \mathrm{NH}_{3}\right)$ & $0.42-0.51$ & $<2$ & Miah et al. $(2013)$ \\
Temperature $\left({ }^{\circ} \mathrm{C}\right)$ & $27-30$ & $25-31$ & Tan and Wang $(2010)$ \\
Hardness $(\mathrm{mg} / \mathrm{L}) \mathrm{CaCO} 3$ & 59.34 & $>50$ & Tan and Wang $(2010)$ \\
\hline
\end{tabular}

in increasing somatic growth in Clodosera species. Meanwhile PUFAs play important roles in reproduction (Wacker \& Creuzburg, 2007) by increasing both growth and survival rate (Fereidouni et al., 2013). Rice bran contains linoleic acid (6.35-6.85\%), and acid $\alpha$ linoleic $(0.2-0.27 \%)$ i.e. fatty acids that are essential for cladosera (Faria et al., 2012; Persson \& Vrede, 2006). Some Clodosera species have the ability to convert acid $\alpha$ linoleic into eicosapentaenoic acid (EPA) and decosahexanoic acid (DHA) with varying abilities (Masclaux et al., 2012). EPA availability in copepod species feed affects eggs production (Jónasdóttir et al., 2009).

M. macrocopa population growth and fecundity (on day 5 and day 7) that were high in rice bran suspension (treatment $\mathrm{A}, \mathrm{B}, \mathrm{C}$, and $\mathrm{D}$ ) were supported by high RNA/DNA ratio on day 5 $(0.20-0.24)$ and day $7(0.36-0.82)$ compared to those of cassava bran suspension (0.19-0.24 and $0.32-0.45$, respectively). RNA/DNA ratio also becomes an indicator of both nutritional condition and growth of marine organisms (Chícharo \& Chícharo, 2008). Feed availability (chlorophyll-a concentration) controls copepod Calanus sinicus growth and increase RNA/DNA ratio during plankton blooming (Ning et al., 2013). Protein concentration increment (from $40 \%$ to $50 \%$ ) in rainbow trout (Oncorhynchus mykiss) larvae significantly increased RNA/DNA ratio (Labh et al., 2014). A high RNA/DNA ratio indicated high protein synthesis capacity per cell and a better nutritional status (Fathallah et al., 2010).

Variations in total Cladosera DNA also reflect changes in reproductive activities. In an organism that reproduces sexually, DNA synthesis is active after fertilization (Kermi et al., 3017). In Cladosera (Moina) that reproduces asexually (parthenogenesis), the cell of the egg will develop into embryo without fertilization i.e. after being placed in the embryonic developmental cavity (Hiruta et al., 2010). Cladosera DNA concentration increases at the beginning of gonadal development (Gorokhova \& Kyle, 2002). Transcription program and active differentiation occur at the end of embryogenesis (Kermi et al., 3017), so that RNA concentration will increase in late developmental period of embrionic growth (Gorokhova \& Kyle, 2002).

A decrease in fecundity of broodstock on day 7 was a consequence of a drop in eggs production in gonads that was followed by a cut in $M$. macrocopa DNA concentration. The rise of $M$. macrocopa DNA/RNA ratio cultured in rice bran suspension on day 7 was due to a decrease in the total M. macrocopa DNA value $(0.078-0.100 \mu \mathrm{g} /$ $\mu \mathrm{g})$ and an increase in total RNA (0.023-0.083 $\mu \mathrm{g} / \mu \mathrm{g})$. The total RNA of M. macrocopa cultured in cassava bran suspension $(0.016-0.039 \mu \mathrm{g} /$ $\mu \mathrm{g})$ also faced a decrease on day 7 . The highest total M. macrocopa RNA concentration on day 7 $(0.083 \mu \mathrm{g} / \mathrm{\mu g})$ was observed in treatment B.

M. macrocopa fed on rice bran suspension had lower feed conversion ratio $( \pm 1.00)$ compared to those fed on cassava bran suspension (7.8-14.1). M. macrocopa cultured in rice bran had a protein content of $53.69 \%$ (dry weight), which was higher than that of cassava bran suspension $(39.5 \%$, dry weight). Protein content of M. macrocopa fed on rice bran suspension was still within the normal range for M. macrocopa i.e. 50\% (Gogoi et al., 2016), while $M$. macrocopa fed on cassava bran suspension had lower protein content.

M. macrocopa culture using rice bran as feed (treatment D) resulted in the highest population peak, being 17,975 individual/L, with a biomass of $439 \mathrm{mg} / \mathrm{L}$ (wet weight) and a FCR of $0.94 \pm 0.09$, which was lower than that of D. magna fed on cassava bran suspension (1.00-2.00). A decrease in feed concentration (rice bran suspension) that was lower than that of treatment $\mathrm{D}$ was caused by a decline in both fecundity and growth. Zadereev and Lopotina (2012), reported a decrease in broodstock fecundity (from 14 to 10) due to a decline in Chlorella vulgaris density from 800 cell $/ \mathrm{mL}$ to $100 \mathrm{cell} / \mathrm{mL}$. 


\section{CONCLUSION}

Rice bran suspension is better than cassava bran suspension as feed in M. macrocopa culture due to high population, fecundity, broodstock percentage, and biomass. M. macrocopa culture using rice bran suspension resulted in high RNA/ DNA ratio, FCR, protein concentration and amino acids concentration compared to cassava bran suspension.

\section{REFERENCES}

AOAC.1995. Official Methods of Analysis of AOAC International. Arlington Virginia USA: AOAC International 16th edition II.

Chícharo MA, Chícharo L. 2008. RNA:DNA ratio and other nucleic acid derived indices in marine ecology: review. International Journal of Molecular Sciences 9: 1453-1471.

Chen R, Wang W, Liu S, Pan J, Li T, Yin Y. 2013. Dietary arginine supplementation altered expression of IGFs and IGF receptors in weaning piglets. Journal of Cell and Animal Biology 7: 44-50.

Choi J, Kim S, Hwan LG, Chang K, Kim D, Jeon K, Park M, Joo J, Kim H, Jeong K. 2016. Effects of algal food quality on sexual reproduction of Daphnia magna. Ecology and Evolution $6: 2817-2832$.

Depauw N, Laureys P, Morales J. 1981 Mass cultivation of Daphnia magna straus on ricebran. Aquaculture 25: 141-152.

Dodson S, Caceras C, Rogers C. 2010. Cladocera and Other Branchiopoda. Ecology and Classification of North American Freshwater Invertebrates Third Edition. San Diego California: Academic Press.

Faria S, Bassinello P, Penteado M. 2012. Nutritional composition of rice bran submitted to different stabilization procedures. Brazilian Journal of Pharmaceutical Sciences 48: 35-45.

Fathallah S, Medhioub MN, Medhioub A, Boussetta H. 2010. Biochemical indices (RNA/DNA ratio and protein content) in studying the nutritional status of Ruditapes decussatus (Linnaeous 1758) juveniles. Aquaculture Research 42: 139-146.

Fereidouni AE, Fathi N, Khalesi MK. 2013. Enrichment of Daphnia magna with canola oil and its effects on the growth, survival and stress resistance of the Caspian Kutum Rutilus frisii kutum larvae. Turkish Journal of
Fisheries and Aquatic Sciences 13: 119-126.

Gogoi B, Safi V, Das DN. 2016. The Cladoceran as live feed in fish culture: A Brief Review. Research Journal of Animal, Veterinary and Fishery Sciences 4: 7-12.

Gorokhova E, Kyle M. 2002. Analysis of nucleic acids in Daphnia: development of methods and ontogenic variations in RNA-DNA content. Journal Plankton Research 24: 511-522.

Hakima B, Khémissa C, Boudjéma S. 2013. Effects food limitation on the life history of Simocephalus expinosus (Cladocera: Daphniidae). Journal Biology Sciences 5: 25-31.

Hiruta C, Nishida C, Tochinai S. 2010. Abortive meiosis in the oogenesis of parthenogenetic Daphnia pulex. Chromosome Research 18: 833-840.

Jobgen WS, Fried SK, Fu WJ, Meininger CJ, Wu G. 2006. Regulatory role for the arginine nitric oxide pathway in metabolism of energy substrates. Journal Nutrition Biochemical: 17: 571-588.

Jónasdóttir SH, Visser1 AW, Jespersen C. 2009. Assessing the role of food quality in the production and hatching of Temora longicornis eggs. Marine Ecology Progress: 382: 139-150.

Kermi C, Furno EL, Mairano D. 2017. Review: Regulation of DNA replication in early embryonic cleavages. Genes 8: 1-21.

Koch U, Creuzburg D, Grossart P, Straile D. 2011. Single dietary amino acids control resting egg production and affect population growth of a key freshwater herbivore. Oecologia 167: 981-989.

Labh SN, Prasad A, Ranjan R. 2014. Effects of dietary protein concentrations on growth and RNA: DNA ratio of rainbow trout (Oncorhynchus mykiss) cultured in Nuwakot district of Nepal. International Journal of Fisheries and Aquatic Studies 1: 184-188.

Li P, Mai K, Trushenski J, Guoyao. 2008. New developments in fish amino acid nutrition: towards functional and environmentally oriented aquafeeds Amino acid: 37: 43-53.

Loh JH, Alan HK, Hii YS, Smith TJ, Lock M, Khoo G. 2013. Impact of potential food sources on the life table of the cladoceran, Moina macrocopa. The Israeli Journal of Aquaculture Bamidgeh 65: 820-828.

Loh JH, Alan Ong HK, Hii YH, Khoo G. 2016. The effects of recirculating aquaculture system effluent water on the growth of Moina 
macrocopa (Straus). International Journal of Zoology Studies: 1: 01-08.

Malla S, Banik S. 2015. Production and application of live food organisms for freshwater ornamental fish larva culture. Advanced Biomedical Research 6: 159-167.

Masclaux H, Bec A, Kainz MK, Perrie F, Desvilettes C, Bourdier G. 2012. Accumulation of polyunsaturated fatty acids by cladocerans: effects of taxonomy temperature and food. Freshwater Biology 57: 696-703.

Mehdipour N, Fallahi M, Takami GA, Vossoughi G, Mashinchian A. 2011. Freshwater green algae Chlorella sp. and Scenedesmus obliquus enriched with B group of vitamins can enhance fecundity of Daphnia magna Iranian Journal of Science and Technology 2: 157-163.

Miah F, Roy S, Jinnat E, Khan ZK. 2013. Assessment of Daphnia, Moina and Cylops in freshwater ecosystems and the evaluation of mixed culture in laboratory. American International Journal of Research in Formal, Applied \& Natural Sciences 4: 1-7.

Murtaza AS, Khawar A, Naheed S. 2011. Effect of processing on nutritional value of rice (Oryza sativa). Journal of Medical Sciences 6: 68-73.

Nagaraju G. 2011. Review reproductive regulators in decapod crustaceans: an overview. The Journal of Experimental Biology 214 : 3-16.

Ning J, Li C, Yang G, Wan A, Sun S. 2013. Use of RNA:DNA ratios to evaluate the condition and growth of the copepod Calanus sinicus in the Southern Yellow Sea Deep Sea Research Part II. Topical Studies in Oceanography 97: 109-116.

Patil SS, Ward AJ, Kumar MS, Ball AS. 2010. Utilising bacterial communities associated with digested piggery effluent as a primary food source for the batch culture of Moina australiensis. Bioresource Technology 101: 3.371-3.378.

Persson J, Vrede T. 2006. Polyunsaturated fatty acids in zooplankton: variation due to taxonomy and trophic position. Freshwater Biology 51: 887-900.

Rietzler AC, Maia-Barbosa PM, Ribeiro MM,
Menendez RM. 2014. The first record of the exotic Moina macrocopa (Straus, 1820) in Minas Gerais State, Brazil. Journal Biology 74: 518-520.

Ramalho AS, Beck S, Farinha CM, Clarke L, Heda GD, Steiner B, Sanz J, Gallati S, Amaral MD, Harris A, Tzetis M. 2004. Methods for RNA extraction, cDNA preparation and analysis of CFTR transcripts. Journal of Cystic Fibrosis $3: 11-15$.

Salvador EM, Steenkamp V, McCrindle CM. 2014. Production consumtion and nutritional value of cassava Manihot utilisima in Mozambique: review. Journal of Agricultural and Biotechnology and Sustainable Development 6: 29-38.

Siddque N, Hassan MM, Khan GQ, Hasan MA, Rahman MZ. 2004. Laboratory culture of Moina with organic and inorganic fertilizers. Bangladesh Journal Fish Research 8: 87-93.

Sorgeloos P, Baeza-Mesa M, Bossuyt E, Bruggeman E, Dobbeleir J, Versichele D, Lavina E, Bernardino A. 1980. Culture of Artemia on rice bran: The conversion of waste product into highly nutritive animal protein. Aguaculture 21: 393-396.

Tan QG, Wang WX. 2010. Interspecies differences in calcium content and requirement in four freshwater cladocerans explained by biokinetic parameters. Limnology Oceanography 55: 1426-1434.

Ventura MJ, Nandinia S, Sarma SS, and Paez CM. 2012. Demography of zooplankton (A. fissa, B. rubens and $M$. macrocopa) fed $C$. vulgaris and $S$. acutus cultured on different media. Journal Tropical Biology 60: 955-965.

Wacker A, Creuzburg MD. 2007. Allocation of essential lipids in Daphnia magna during exposure to poor food quality. Functional Ecology 21: 738-747.

Zadereev E, lopatina T. 2012. the effect of food concentration on the juvenile somatic growth rate of body length, fecundity and the production of resting eggs by Moina brachiate single females. Journal of Siberian Federal University Biology 4: 427-438. 